This is a self-archived - parallel published version of this article in the publication archive of the University of Vaasa. It might differ from the original.

\title{
A values-beliefs-attitude model of local food consumption : an empirical study in China and Denmark
}

Author(s): Zhang, Ting; Grunert, Klaus G.; Zhou, Yanfeng

Title: $\quad$ A values-beliefs-attitude model of local food consumption : an empirical study in China and Denmark

Year: $\quad 2020$

Version: Final draft (post print, aam, accepted manuscript)

Copyright C 2020 Elsevier Inc. This manuscript version is made available under the Creative Commons Attribution-NonCommercial-NoDerivatives 4.0 International (CC BY-NC-ND 4.o) license, https:// creativecommons.org/licenses/by-nc-nd/4.o/

Please cite the original version:

Zhang, T., Grunert, K.G., \& Zhou, Y, (2020). A values-beliefs-attitude model of local food consumption : an empirical study in China and Denmark. Food quality and preference 83 . https://doi.org/10.1016/j.foodqual.2020.103916 


\section{Journal Pre-proofs}

A values-beliefs-attitude model of local food consumption: An empirical study in China and Denmark

Ting Zhang, Klaus G. Grunert, Yanfeng Zhou

PII:

S0950-3293(19)30999-1

DOI: https://doi.org/10.1016/j.foodqual.2020.103916

Reference:

FQAP 103916

To appear in:

Food Quality and Preference

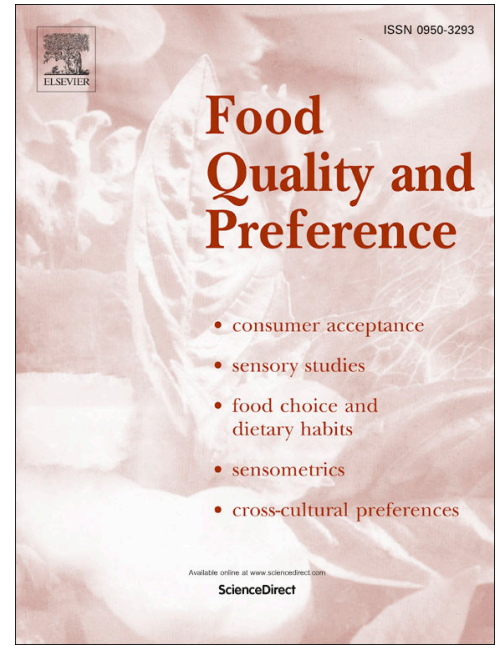

Received Date: $\quad 16$ December 2019

Revised Date: $\quad 22$ February 2020

Accepted Date: $\quad 22$ February 2020

Please cite this article as: Zhang, T., Grunert, K.G., Zhou, Y., A values-beliefs-attitude model of local food consumption: An empirical study in China and Denmark, Food Quality and Preference (2020), doi: https:// doi.org/10.1016/j.foodqual.2020.103916

This is a PDF file of an article that has undergone enhancements after acceptance, such as the addition of a cover page and metadata, and formatting for readability, but it is not yet the definitive version of record. This version will undergo additional copyediting, typesetting and review before it is published in its final form, but we are providing this version to give early visibility of the article. Please note that, during the production process, errors may be discovered which could affect the content, and all legal disclaimers that apply to the journal pertain.

(C) 2020 Published by Elsevier Ltd. 


\section{A values-beliefs-attitude model of local food consumption: An empirical study in China and Denmark}

Ting Zhang ${ }^{\mathrm{a}}$, Klaus G. Grunert ${ }^{\mathrm{b}, \mathrm{c}} \&$ Yanfeng Zhou $^{\mathrm{a}^{*}}$

${ }^{\text {a }}$ Sun Yat-sen Business School, Sun Yat-sen University, 135 Xingang West Road, 510275, Guangzhou, China

${ }^{b}$ MAPP Centre, Department of Management, Aarhus University, Fuglesangs Allé 4,8210 Aarhus V, Denmark ${ }^{\mathrm{c}}$ School of Marketing and Communication, University of Vaasa, P.O. Box 700, 65101 Vaasa, Finland

* Corresponding author: Yanfeng Zhou, email: sysuzyf@163.com 


\title{
A values-beliefs-attitude model of local food consumption: An empirical study in China and Denmark
}

\begin{abstract}
Consumers' and policy makers' interest in local foods is growing. Accordingly, researchers are also increasingly paying attention to the consumption of local foods. Studies have identified preference for local foods as an emergent consumer ideology called "locavorism", but they have not yet addressed its antecedents or put it into a theoretical context. In addition, extant research provides several insights into local food buying behaviour in developed economies (e.g., USA, UK, Germany, or Italy); however, studies simultaneously conducted in developed and emerging economies are lacking. To address these research gaps, this study develops a conceptual framework with proposed relationships among values, beliefs (locavorism and fresh start mindset), and attitudes towards and intentions to purchase local foods in China and Denmark. We conducted an online survey in China and Denmark that evaluated our constructs with pre-developed multiple-item measures. Using structural equation modelling to test the integrated model, we find that values and long-term orientation are antecedents of consumer beliefs but the influences of values on consumer beliefs differ between collectivistic-dominated China and individualistic-dominated Denmark. Specifically, collectivistic values are significantly and positively related to locavorism in both countries, while individualistic values are strongly linked to locavorism only in Denmark; collectivistic values have no effects on fresh start mindset for the two samples, but individualistic values are significantly and positively related to a fresh start mindset in Denmark. In addition, consumer beliefs are significantly and positively associated with attitudes towards and intentions to buy local foods. Local food marketers can use our findings to target their communications more effectively.

Keywords: Values; Beliefs; Locavorism; Local food consumption; Fresh start mindset; Structural equation modelling
\end{abstract}

\section{Introduction}

Local food consumption has recently become a popular and growing trend (Skallerud \& Wien, 2019) in various parts of the world. For example, it is one of the fastest growing food trends in the United States (Nie \& Zepeda, 2011); industry estimates show that U.S. local food sales totalled at least $\$ 12$ billion in 2014 and will hit \$20 billion by 2019 (Vilsack, 2016). Moreover, a report by the Federal Ministry of Food and Agriculture (BMEL, 2018) indicates that $78 \%$ of German consumers value the food from their region. Meanwhile, policy makers have provided funding and policies to support the development of local food systems. For example, the U.S. Department of Agriculture (USDA) has invested more than \$20 million each year since 2017 to the Farmers Market Promotion Program and Local Food Promotion Program to support the development and expansion of local and regional food markets, enterprises, and producer-to-consumer marketing. In the United Kingdom, the government encourages consumers to buy more locally produced food (Chambers, Lobb, Butler, Harvey, \& Traill, 2007), and in 2014, the Department for Environment, Food \& Rural Affairs published a policy paper encouraging the U.K. government to buy locally. 
Why have local foods attracted so much attention? Manifold reasons drive consumers' local food consumption. On the one hand, the advent of global food systems has raised consumers' concerns about the transparency and safety of their foods (Birch, Memery, \& Kanakaratne, 2018). On the other hand, local foods per se possess beneficial attributes. Researchers have demonstrated the health, social, economic, and environmental benefits of local foods (e.g., Coelho, Coelho, \& Egerer, 2018; Denver \& Jensen, 2014; Meyerding, Trajer, \& Lehberger, 2019). Recently, research has defined preferences for local foods as an emergent consumer ideology called "locavorism", which can be understood as a set of normative beliefs (Reich, Beck, \& Price, 2018). Consumers believing in locavorism view local foods as tasty, nutritious, trustworthy, and beneficial to the local community. Previous research has mapped the psychological structure of locavorism and developed and validated an instrument to measure locavorism beliefs. However, no research has investigated its antecedents. Reich et al. (2018) suggest that future research should examine the relationship between locavorism and consumer value systems, which we address herein. In addition, we look at long-term orientation as a determinant of locavorism. Long-term orientation is a time orientation emphasising future rewards (Hofstede \& Minkov, 2010). Attributes of local foods, such as healthiness and sustainability, could benefit people in the future. Finally, we investigate the possible importance of a fresh start mindset for consumers' intentions to buy local foods. Grounded in a future focus, the fresh start mindset is a belief about the possibility to make a new start in life and it is positively related to consumer health-related behaviours (Price, Coulter, Strizhakova, \& Schultz, 2018). Although the fresh start mindset and long-term orientation both have connections with future, previous research has not investigated their influences on local food consumption.

Researchers investigating consumer attitudes and behavioural intentions towards local foods have mainly carried out their studies in developed countries (Bianchi \& Mortimer, 2015), such as the United States, the United Kingdom, Germany, and Italy; research based on emergent economies remains limited. These studies recommend additional cross-national studies because the sociocultural background and other national contexts (e.g., economic background, cultural differences) could have different influences on attitudes and behaviours (Feldmann \& Hamm, 2015; Skallerud \& Wien, 2019). Thus, more work is necessary to determine the factors influencing consumer attitude and behaviour towards local foods in different cultural and economic contexts (Campbell, 2013).

To this end, the current research aims to examine a values-beliefs-attitude-intention model of local food consumption both in a developing and in an emergent economy. Specifically, we explore the antecedent factors (i.e., personal values and long-term orientation) in predicting consumer beliefs of locavorism and fresh start mindset and then examine the influences of these two sets of beliefs on consumer attitudes towards and intentions to purchase local foods in China and Denmark. In doing so, this study fills a research gap in local food research by addressing the antecedents of locavorism and by putting the locavorism construct into an integrated network of antecedents and consequences. Moreover, we expand current local food research by using samples from two countries. The findings of this study provide implications for local food marketers.

\section{Conceptual development and hypotheses}

\subsection{Local food}


No consensus exists on the definition of "local food". The key elements of existing definitions range from distance of food travel (from 10-31 miles to as high as 400 miles; Adams \& Adams, 2011; Canadian Food Inspection Agency, 2019; Martinez et al., 2010), driving hours (e.g., within six to seven hours; Zepeda \& Leviten-Reid, 2004), geographic boundaries (e.g., given states, regions, countries; Conner, Montri, Montir, \& Hamm, 2009), regional specialties (Adams, 2018), and marketing distribution channels (e.g., farmers' markets, farm retailers; Bavorova, Unay-Gailhard, \& Lehberger, 2016) to emotion- or relation-related foods (e.g., foods from one's hometown, neighbours, or relatives; Feldmann \& Hamm, 2015). Researchers have demonstrated that local food cannot be regarded as a definite entity and consumers perceive local food differently according to their spatial and social context (Carroll \& Fahy, 2014). Therefore, we avoided defining the term specifically in this study. Instead, we instructed participants to respond to the relevant questions about local food according to their own perceptions of "local".

\subsection{Values}

Schwartz (1994, p. 21) defines values as "desirable transsituational goals, varying in importance, that serve as guiding principles in the life of a person or other social entity”. Schwartz (1992) distinguishes 10 value domains: stimulation, self-direction, tradition, conformity, security, power, achievement, universalism, benevolence, and hedonism. Research has highlighted the influences of values on consumer attitudes towards, preferences for, and consumption of different categories of foods. For example, collectivistic values positively influence Chinese consumers' environmental attitudes, which in turn influence attitudes towards green food, whereas individualistic values do not have a significant relationship to attitudes towards green food (Perrea et al., 2014). Caracciolo et al. (2016) find that consumer preferences for cleaner pork production are strongly related to individual values. In addition, studies show that collectivistic values affect consumer purchase and use of organic foods (Mørk, Bech-Larsen, Grunert, \& Tsalis, 2017; Thøgersen, Zhou, \& Huang, 2016). In the context of local foods, Zepeda and Deal (2009) successfully use alphabet theory as a determinant explaining consumer motivations for purchasing local foods. They demonstrate that particular values, beliefs, and norms shape food shoppers' attitudes towards local foods and motivate their local food purchases; furthermore, many participants in their study emphasized local foods because of value issues. Thus, we propose that values are related to consumers' preference for local foods.

\subsection{Long-term orientation}

The notion of long-term orientation, as Hofstede and Minkov (2010) discuss, is founded on the time orientation framework, suggesting an orientation that emphasises future rewards. In practice, many researchers use the terms "long-term orientation" and "future orientation" interchangeably to examine the influence of time orientation on individual attitudes and behaviours (Venaik, Zhu, \& Brewer, 2013). Long-term-oriented individuals tend to emphasise the future rewards of their current decisions. People with a high level of long-term orientation value planning, perseverance, and hard work for future benefit (Bearden, Money, \& Nevins, 2006). Joireman, Shaffer, Balliet, and Strathman (2012) find that highly future-oriented individuals are more likely to engage in healthy eating and exercise. Dassen, Houben, and Jansen (2015) also confirm that a focus on future is positively related to healthy eating. Some of the benefits of local foods could be in the 
future, such as human health and sustainability (Rudy, 2012). Thus, we propose that with increasing long-term orientation, the likelihood of consumers perceiving the benefits of local foods for both self and others will increase.

\subsection{Locavorism}

A locavore refers to "a person whose diet consists only or principally of locally grown or produced food" 1 . In the food marketing context, locavores are consumers who value and buy foods that are officially labelled as locally produced, from farmers' markets, or self-produced (Stanton, Wiley, \& Wirth, 2012). Understanding of locavores' perception of and beliefs about local foods is important for local food research. Researchers have identified several reasons for consuming local foods (e.g., Roininen, Arvola, \& Lähteenmäki, 2006; Zepeda \& Deal, 2009), which can be divided into self-beneficial and other-beneficial motivations. Self-beneficial motivations include freshness, transparency of food sources, superior taste and quality, and security. Other-beneficial motivations involve concerns about animal welfare, environmental sustainability, and support of local labour/community.

Local food consumption is not just a matter of food miles; it also signals "a mindset about shared commitments to various forms of environmental sustainability, community revitalization, human health, and animal welfare" (Rudy, 2012, p. 28). Locavorism is a reflection of beliefs about developing and maintaining relationships between farmers and consumers and between humans and the nature (Fitzgerald, 2016). As a concept, locavorism is relatively new and recent; thus, current research lacks a formal construction of its definition.

According to Reich, Beck, and Price (2018), various views can be used to construct locavorism. From the simplistic view, the locavorism construction characterises locavores as consumers with strong local food preferences. From a more complex view, locavorism can be understood as the intersection of several cultural and economic phenomena that require explanations through a multidimensional theoretical lens and framework. To balance these views, Reich, Beck, and Price provide a comprehensive and parsimonious view of locavorism as a system of beliefs comprising three dimensions: lionisation, opposition, and communalisation. Lionisation refers to a belief that local foods possess superior taste and quality. Jekanowski, Williams, and Schiek (2000) find that consumers' belief in the superior quality of local foods plays a critical role in predicting their willingness to buy local products. Opposition pertains to a belief in opposing distant foods. Food that has travelled a long distance makes it difficult for consumers to understand the dynamics of the global food supply chains (Meyerding et al., 2019). By contrast, because of short travelled distance, local foods are perceived as transparent (knowing elements such as where the foods are grown, who sells the foods, and where the shopper is located), trusted, familiar (Blake, Mellor, \& Crane, 2010), and fresh (Chambers et al., 2007). Communalisation refers to building and supporting the local community. Using laddering and word association techniques, Roininen et al. (2006) show that participants associate local foods with freshness, short transport, contribution to local economy, and transparency.

Using semistructured interviews, Zepeda and Deal (2009) show that positive perception of local foods is based on values, beliefs, and norms and that existing values influence beliefs, which in turn support attitudes

\footnotetext{
${ }^{1}$ https://www.lexico.com/en/definition/locavore [Accessed at July 15 2019].
} 
towards and behaviour of buying local. Thus, values and beliefs shape consumers' attitude towards and motivation to purchase or not purchase local foods. Previous research has shown a positive influence of belief in local products on consumers' attitudes towards and intentions to buy local foods. For example, when consumers recognize the benefits of locally produced products, such as that locally produced products are more environmentally friendly/healthier/tastier and have better quality, they are willing to pay a premium price for them (Denver \& Jensen, 2014). Perceived freshness of local foods and the feeling of supporting local farmers have a positive relationship to consumers' local food purchase (Bavorova et al., 2016). Adams and Adams (2011) find that farmers' market shoppers are willing to pay a large price premium for local foods. Thus, we propose that consumers who endorse collectivistic values are more likely to exhibit greater locavorism, and the greater the locavorism, the more positive are the attitude towards buying local foods.

\subsection{Fresh start mindset}

Rucker and Galinsky (2016, p. 161) define a mindset as "a psychological orientation that affects the selection, encoding, and retrieval of information"; it drives a person's evaluations, actions, and responses. Researchers have emphasised the impact of various mindsets on consumer preferences, behaviours, and attentions (e.g., de Boer, Schösler, \& Aiking, 2017; Macdonnell, \& White, 2015; Reczek, Trudel, \& White, 2018; Werthmann, Jansen, \& Roefs, 2016). Price, Coulter, Strizhakova, and Schultz (2018) introduce the fresh start mindset concept and link it to consumer beliefs and behaviours. They define it as "a belief that people can make a new start, get a new beginning, and chart a new course in life, regardless of their past or present circumstances" (p. 21) and find that it influences consumer preferences, choices, and behaviours. From the consumer transformation perspective, which emphasises creating changes and improvements in consumers and communities' well-being to gain a more positive future (Anderson et al., 2013; Mick, Pettigrew, Pechmann, \& Ozanne, 2012), the fresh start mindset is rooted in an ideology of individualism (Price et al., 2018). People in more individualistic cultural contexts (e.g., Americans) perceive greater possibility to change their choices (Kim \& Drolet, 2003). Thus, it could be inferred that people from more individualistic cultures should have higher levels of fresh start mindset than people from more collectivistic cultures.

On the one hand, people consume local food because they believe it possesses better quality (Cranfield, Henson, \& Blandon, 2012; Jekanowski et al., 2000), freshness, wholesomeness, and taste (Darby, Batte, Ernst, \& Roe, 2008; Thomas \& Mcintosh, 2013), as well as higher levels of safety and transparency (Meyerding et al., 2019) - in other words, benefits for the consumer him-/herself. On the other hand, local foods have direct benefits to the local farmers, economy, and community (Zepeda \& Leviten-Reid, 2004), and their production is more sustainable (Schmitt et al., 2017), which could be perceived as beneficial to others. Research indicating that local food production substitutes or complements organic food production has suggested the importance of "local" attributes. For example, the results from a qualitative study show that many consumers buying local food regard their food purchase behaviour as "an evolution from organic to local in response to the increasing commercialization of organic foods and industrialization of organic farming practices", emanating from distrust of corporations taking over organic food production (Zepeda \& Deal, 2009, p. 702). Consumers are more likely to pay for organic local apples than organic non-local apples (Costanigro, Kroll, Thilmany, \& Bunning, 2014). Hempel and Hamm (2016) find that organic-minded consumers prefer locally produced food over food from far away, and they would buy more organic food as well as more local food. Additionally, 
current global food systems are socially and environmentally unsustainable and the need for a comprehensive food system transformation is widely acknowledged (Sellberg, Norström, Peterson, \& Gordon, 2020). Localization is one process/outcome that is proffered as key to the transformation (Carroll \& Fahy, 2014). Thus, it could be concluded that local food consumption is a transformative behaviour in which consumers change from buying industrialized foods that have travelled long distances to local foods to further their own well-being and that of their communities (i.e., pursue positive outcomes for both oneself and others). Fresh start mindset emphasizes the possibility of building a new and positive future and is empirically found to be directly and positively related to behaviours that help consumers make changes to achieve a better future for both their own lives (i.e., self transformations; e.g., investing greater health-related efforts) and others' lives (i.e., other transformations; e.g., more support for people in need) (Price et al., 2018). White, Habib, and Hardisty (2019) suggest the direct and positive association between fresh start mindset and sustainable consumer behaviour habits. Thus, we predict that people with a stronger fresh start mindset will have a higher likelihood to purchase local foods.

\subsection{Attitude towards and intentions to purchase local foods}

Attitude towards and intention to purchase foods are two important and popular concepts in food consumption research. We view attitude towards buying local foods as an evaluative construct, which is different from attitude towards local product quality, food safety, consumers' personal health, and societal benefits (Feldmann \& Hamm, 2015). Abundant research on consumer behaviour regarding food products has shown that attitudes are positively related to intentions to purchase (e.g., Bolos, Lagerkvist, \& Kulesz, 2019; Menozzi, Sogari, Veneziani, Simoni, \& Mora, 2017; Qi \& Ploeger, 2019). In the local food consumption literature, researchers have provided ample evidence to demonstrate the positive impact of attitudes on intentions to purchase local foods. For example, using survey data, Zepeda and Li (2006) find that compared with key demographic characteristics, attitudes towards local foods are better predictors of buying local foods. Moreover, research has confirmed that consumer attitudes towards eating local foods are positively related to local food purchasing behaviour (Skallerud \& Wien, 2019). Therefore, we propose that attitude towards buying local foods is positively associated with intentions to purchase local foods.

Zepeda and Deal (2009) propose alphabet theory, which combines value-belief-norm theory (Stern, Dietz, Abel, Guagnano, \& Kalof, 1999), attitude-behaviour-context theory (Guagnano, Stern, \& Dietz, 1995), demographics, knowledge, information seeking, and habits, and they use this theoretical framework to explain determinants of organic and local food buying behaviour. According to alphabet theory, values are direct determinants of beliefs (e.g., that local foods are better for health), and beliefs influence behaviours. Ample research has confirmed the value-belief-attitude (intention) relationship (e.g., Cembalo et al., 2016; Gkargkavouzi, Halkos, \& Matsiori, 2019; Kang, Jun, \& Arendt, 2015; Stern \& Dietz, 1994). Therefore, in line with the aforementioned literature, we hypothesise the following (for the conceptual framework of this study, see Fig. 1):

H1: Collectivistic values are significantly and positively related to locavorism. This effect exists in both China and Denmark.

H2: The relationship between individualistic values and locavorism is different in China and Denmark. Specifically, in Denmark, it is significant and positive, whereas in China, individualistic values are not related 
to locavorism.

H3: The relationships between collectivistic/individualistic values and fresh start mindset are different in China and Denmark. Specifically, (a) collectivistic values have no association with fresh start mindset in either China or Denmark; (b) by contrast, in Denmark, individualistic values are significantly and positively related to fresh start mindset, while in China, individualistic values are not related to fresh start mindset.

H4: Long-term orientation is significantly and positively related to (a) locavorism and (b) fresh start mindset.

H5: Locavorism is significantly and positively related to attitude towards buying local foods.

H6: Fresh start mindset is positively related to intention to purchase local foods.

H7: Attitude towards local foods consumption is positively related to intention to purchase local foods.

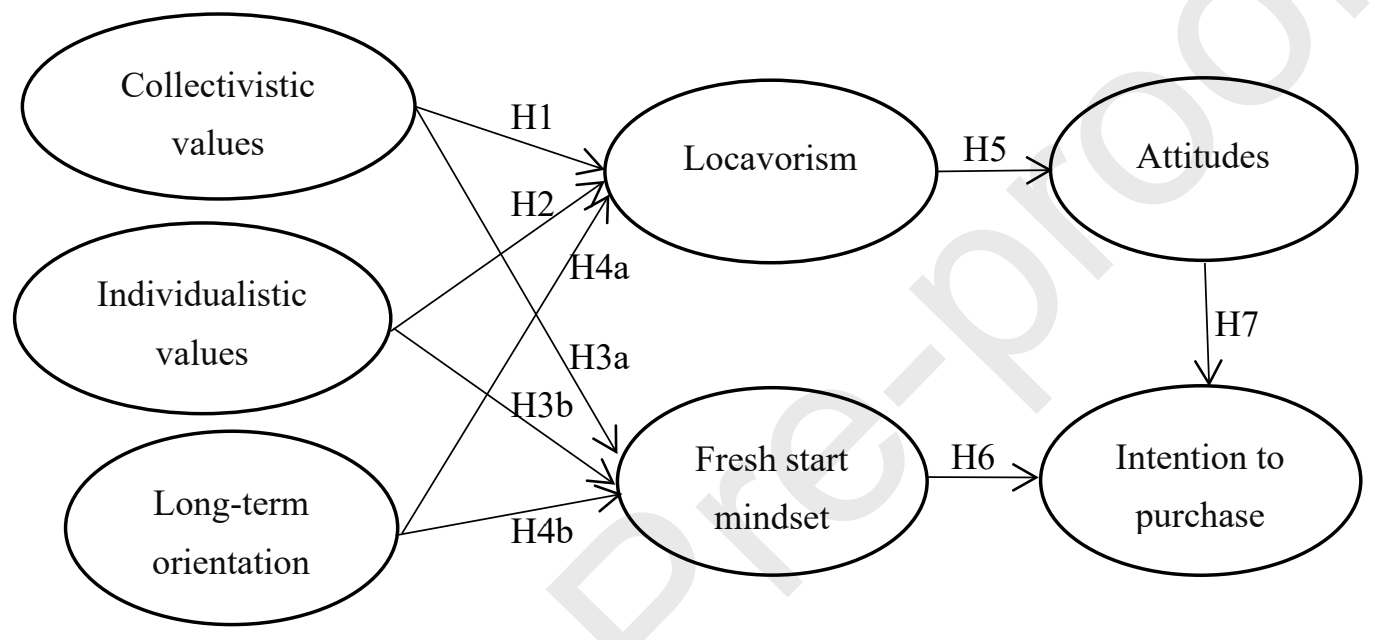

Fig.1 Conceptual framework

\section{Method}

\subsection{Measures}

We used pre-developed instruments to measure the constructs. We evaluated locavorism with 11 items from Reich et al. (2018) using a 7-point scale ( 1 = "strongly disagree", 7 = "strongly agree"; Cronbach's $\alpha$ : China = 0.806, Denmark $=0.829)$. We used the 21-item version of Schwartz's Portrait Value Questionnaire used in the European Social Survey for measuring individual values (Bilsky, Janik, \& Schwartz, 2011; Schwartz et al., 2001), along with an attention check: "Please select the circle closest to 'Very much like me' for this question". The 21 items were administered in a male or female version depending on the participant's gender. The items were formulated on the basis of a 6-point scale ( 1 = "not like me at all", 6 = "very much like me"; Cronbach's $\alpha$ : China/Denmark: collectivistic values $=0.834 / 0.829$, individualistic values $=0.841 / 0.831)$. We determined long-term orientation with three items from Kopalle, Lehmann, and Farley (2010), anchored by 1 ("strongly disagree") and 7 ("strongly agree") (Cronbach's $\alpha$ : China $=0.739$, Denmark $=0.682$ ). Attitude towards buying local foods was measured with four semantic differential items (Ajzen \& Fishbein, 1980), anchored by 1 to 7 (Cronbach's $\alpha$ : China $=0.941$, Denmark $=0.893$ ). We measured intention to purchase local foods with three items adapted from Reich, Kupor, and Smith (2017) and Reich et al. (2018): "How likely is it 
that you will purchase local foods?" (1 = "not likely at all", 7= "extremely likely"); "How likely is it that you will buy your basic food items from a neighbourhood grocery store that offers locally produced food items?" ( 1 = "not likely at all", 7 = "extremely likely"); and "Next time when you buy a food, you will take local foods into consideration" ( 1 = "strongly disagree", 7 = "strongly agree"; Cronbach's $\alpha$ : China $=0.911$, Denmark = 0.904). We evaluated fresh start mindset with six items from Price et al. (2018) using a 7-point scale $(1=$ "strongly disagree", 7 = "strongly agree"; Cronbach's $\alpha$ : China $=0.888$, Denmark $=0.914)$. All items are listed in the Appendix.

\subsection{Data collection and sample}

\subsubsection{Pretest}

The aim of the pretest was to test the reliability and validity of the measurement instruments. The questionnaire was originally developed in English, and the pretest was carried out in English in Denmark and Chinese in China. We used convenience sampling to collect the data in both Denmark and China. The questionnaire was translated into Chinese, and two overseas Chinese doctoral students checked the translation. Participants were paid $¥ 4$ to fill out the survey in China. In Denmark, student volunteers from the Department of Management, Aarhus University, filled out the questionnaires. We obtained 200 and 86 valid samples from China and Denmark, respectively.

\subsubsection{Main survey}

We used the same questionnaire as that of the pretest for the main survey, except that we screened out participants who were not responsible for shopping for food in the household. At the beginning of the questionnaire, participants were informed that their information would be kept confidential and anonymous, that they should answer the questions according to their own perceptions, views, and opinions, and that there were no "right" or "wrong" answers.

In China, the first and third authors conducted the data collection, using the most popular online survey platform (Wenjuanxing) to program the questionnaire and generate an anonymous link. Wenjuanxing is a national platform launched in 2006 in China. Its users have released more than 59.09 million questionnaires and collected over 4.255 billion responses. We used convenience sampling to collect the data in April 2019: we sent the anonymous link to friends and colleagues and asked them to forward the link to people they knew. Each participant received $¥ 3$ as a reward. The survey was fully completed by 300 participants. After removing the participants who used the same scores to rate all values items, 282 valid responses remained. The demographic profiles (Table 1) show that female respondents are mostly responsible for household food shopping in China, which is consistent with the reality that women take more responsibility for household duties. Most participants were between 26 and 44 years of age, had a higher-than-average level of education, and described their financial situation as not very good or modest.

In Denmark, the questionnaire was translated into Danish and then back-translated to check the validity of the translation with the help of a language expert. We used Qualtrics to program the questionnaire and manage access to panels, employing random sampling to collect the data in April 2019. We received 306 valid 
responses, and the sample is representative of the Danish population in terms of gender, age, education, and financial situation.

\section{Table 1}

Participants' sociodemographic characteristics.

\begin{tabular}{|c|c|c|c|}
\hline \multirow[b]{2}{*}{$\mathrm{N}$ : } & \multicolumn{2}{|l|}{ China } & Denmark \\
\hline & \multicolumn{2}{|l|}{282} & 306 \\
\hline \multicolumn{4}{|c|}{ Responsibility for household food shopping (\%) } \\
\hline Fully responsible & \multicolumn{2}{|l|}{67.4} & 51.0 \\
\hline Partly responsible & \multicolumn{2}{|l|}{32.6} & 49.0 \\
\hline \multicolumn{4}{|l|}{ Gender (\%) } \\
\hline Male & \multicolumn{2}{|l|}{30.5} & 50.0 \\
\hline Female & \multicolumn{2}{|l|}{69.5} & 50.0 \\
\hline \multicolumn{4}{|l|}{ Age (years) (\%) } \\
\hline $18-25$ & 12.4 & & 11.4 \\
\hline $26-34$ & 52.1 & & 18.0 \\
\hline $35-44$ & 31.6 & & 15.0 \\
\hline $45-60$ & 3.9 & & 34.3 \\
\hline More than 60 & 0 & & 21.2 \\
\hline \multicolumn{4}{|l|}{ Education (\%) } \\
\hline Primary school & 2.5 & Primary school & 13.1 \\
\hline Middle school & 7.4 & High school & 16.3 \\
\hline High school & 6.4 & Vocational college education & 34.0 \\
\hline Vocational college education & 8.2 & University first degree (e.g. BA, BSc) & 22.5 \\
\hline Bachelor's & 48.5 & University higher degree (Masters, MBA, PhD) & 13.4 \\
\hline Master's & 25.2 & Professional higher education (e.g., to qualify as & 0.7 \\
\hline Doctorate & 1.1 & a lawyer, an accountant) & \\
\hline Others & 0.7 & & \\
\hline \multicolumn{4}{|l|}{ Financial situation (\%) } \\
\hline Not very good & 41.1 & & 6.9 \\
\hline Difficult & 4.6 & & 12.7 \\
\hline Modest & 46.1 & & 36.6 \\
\hline Reasonable & 7.5 & & 35.6 \\
\hline Well-off & 0.7 & & 8.2 \\
\hline \multicolumn{4}{|l|}{ Residence (\%) } \\
\hline City & 82.3 & & 30.1 \\
\hline Town & 9.9 & & 48.0 \\
\hline Rural area & 7.8 & & 21.9 \\
\hline
\end{tabular}




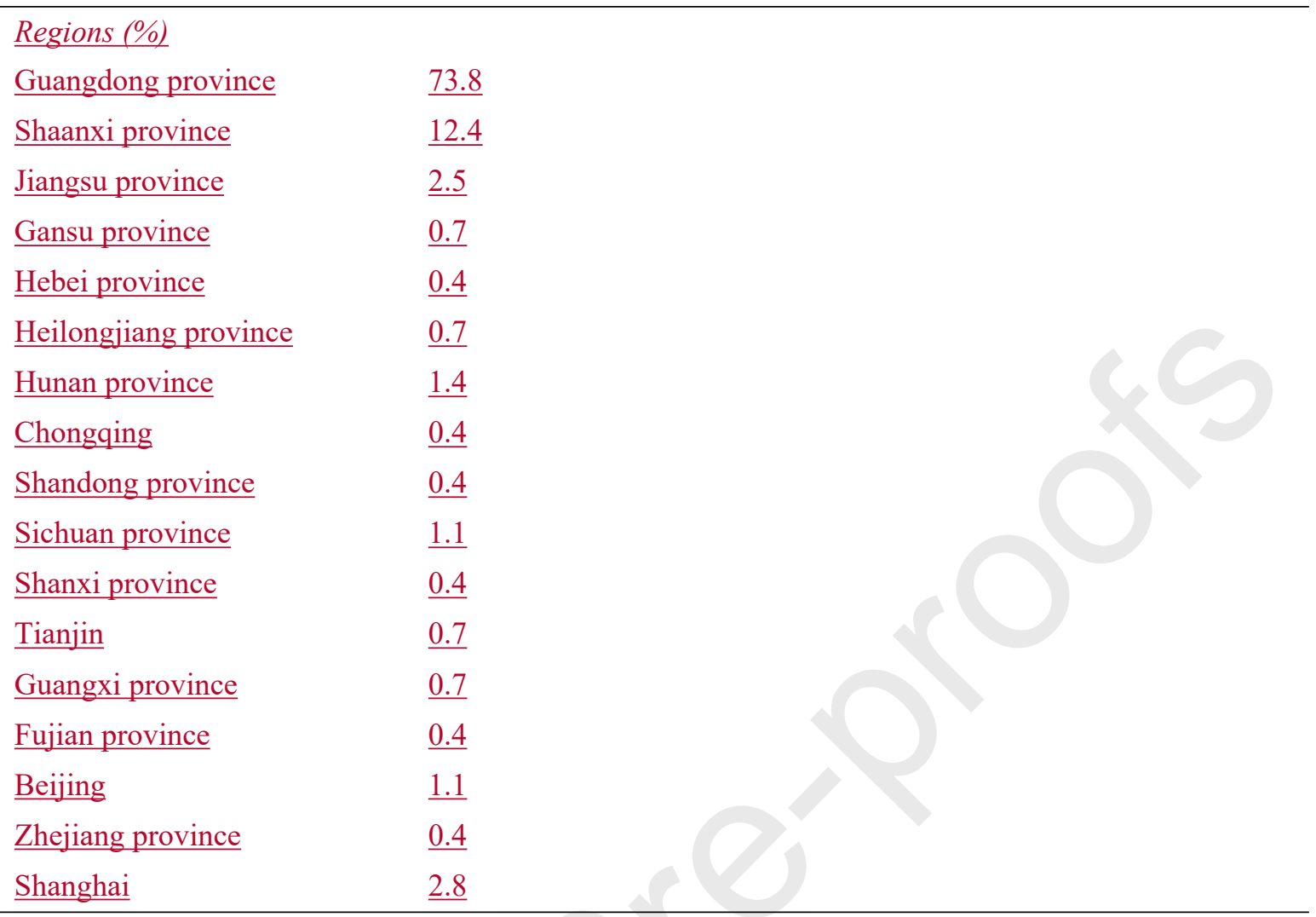

Note: Because the education systems in China and Denmark differ, we designed the options of education levels according to the respondents' country.

\subsection{Statistical method}

We conducted the descriptive analyses and analyses of bivariate relationships between the constructs using SPSS 25. We analysed relationships as specified in the conceptual model with structural equation modelling using AMOS 25.

\subsection{Measurement invariance}

To account for some participants rating all values relatively high or low, such that intercorrelations among values are biased upward we standardized each participant's ratings to eliminate this bias (Schwartz \& Boehnke, 2004). To this end, we standardized scores for each participant across the 10 value domains to account for response tendencies and respondent-specific variation ${ }^{2}$, and we used these standardized value scores in subsequent analyses.

We tested the cross-national measurement invariance by means of nested multiple-group confirmatory factor analysis (CFA). According to Steenkamp and Baumgartner (1998), when the purpose of the study is to explore the strength of relationships cross-nationally, as is the case in this study, at least configural and (partial) metric

\footnotetext{
${ }^{2}$ Readers can contact the first author for information on calculation of the standardized scores.
} 
invariance is required. Configural invariance exists when the pattern of salient and non-salient factor loadings on included latent constructs is the same across countries. Configural invariance is supported when there is an acceptable fit for the joint CFA model across countries. We built a multi-group CFA model including all the multi-item constructs (i.e., locavorism, collectivistic values, individualistic values, long-term orientation, attitude towards buying local foods, intention to purchase local foods, and fresh start mindset) and performed CFA analysis. Because the locavorism, collectivistic values, and individualistic values are multi-dimensional constructs, we used second-order measurement models ${ }^{3}$ for them in the process of multi-group CFA analysis.

Metric invariance exists when factor loadings are identical across countries. In addition to the factor loading fixed at unity to define the scale of each latent construct, we constrained one additional factor loading per latent construct to be equal across the Chinese sample and Danish sample. The results of the invariance test are reported in Table 2. Fit indices of the first row show that the unconstrained multi-group CFA model has an acceptable fit to the data, in support of configural invariance. The second row shows an acceptable fit of the constrained multi-group CFA model (one additional factor loading per latent construct to be equal across the Chinese sample and the Danish sampleChina and Denmark), and the third row shows that the change in fit when imposing equality constraints is not significant, suggesting that the model also possesses partial metric invariance.

Table 2

Measurement invariance test.

\begin{tabular}{|c|c|c|c|c|c|c|c|c|c|c|}
\hline & Chi-square & $\mathrm{df}$ & $\mathrm{CMIN} / \mathrm{df}$ & $p$ & NFI & RFI & IFI & TLI & CFI & RMSEA \\
\hline $\begin{array}{l}\text { Configural invariance } \\
\text { model }\end{array}$ & $3,762.178$ & 2,054 & 1.832 & 0.000 & 0.787 & 0.766 & 0.891 & 0.878 & 0.889 & 0.038 \\
\hline $\begin{array}{l}\text { Partial metric } \\
\text { invariance model }\end{array}$ & $3,775.501$ & 2,061 & 1.832 & 0.000 & 0.787 & 0.766 & 0.890 & 0.878 & 0.889 & 0.038 \\
\hline $\begin{array}{l}\text { Change in fit when } \\
\text { imposing equality } \\
\text { constraints }\end{array}$ & 13.323 & 7 & 0 & 0.065 & 0.000 & 0.000 & -0.001 & 0.000 & 0.000 & 0.000 \\
\hline
\end{tabular}

Notes: $\mathrm{CMIN} / \mathrm{df}=$ chi-square mean/degree of freedom, $\mathrm{NFI}=$ normed fit index; RFI $=$ relative fit index, IFI = incremental fit index; TLI $=$ Tucker - Lewis index; CFI $=$ comparative fit index; RMSEA $=$ root mean square error of approximation.

\section{Results}

\subsection{Means and bivariate relationships}

We first analysed the mean and standard deviation of the variables for the two countries (see Table 3) and then analysed correlations between the 10 value domains and locavorism as well as fresh start mindset (see Table 4). According to Schwartz and Boehnke (2004, p. 253), one critical assumption of value theory is that

\footnotetext{
${ }^{3}$ The complete measurement model can be obtained from the first author.
} 
"actions that express any value have consequences that conflict or are compatible with the pursuit of other values". The conflict suggests that the correlations between values on opposite sides of the value diagram should be negative. Our results are consistent with this assumption. Likewise, in line with the theory, we found that adjacent values in the value diagram were significantly related (e.g., universalism and benevolence; $r=$ 0.359). When using adjacent values as predictors for other constructs, problems of multicollinearity can arise. Davidov, Schmidt, and Schwartz (2008) and Thøgersen et al. (2016) suggest two possible ways to deal with multicollinearity: merging adjacent value domains or selecting value domains according to the strength of their relationship to the construct to be explained. In line with Thøgersen et al. (2016), we chose the latter approach. The results of bivariate relationships showed that among the five domains making up collectivistic values, benevolence was positively and significantly related to locavorism in both the Chinese $(r=0.165)$ and Danish $(\mathrm{r}=0.131)$ samples. Among the values making up individualistic values, stimulation was positively and significantly related to locavorism $(r=0.125)$ and fresh start mindset $(r=0.183)$ in the Danish sample. Thus, we kept the benevolence and stimulation in the subsequent analyses as manifestation of collectivistic values and individualistic values.

Table 3

Means and standard deviations for constructs.

\begin{tabular}{lllll}
\hline & \multicolumn{2}{l}{ China $(\mathrm{N}=282)$} & \multicolumn{2}{l}{ Denmark $(\mathrm{N}=306)$} \\
\hline & Mean & $\begin{array}{l}\text { Standard } \\
\text { Deviation }\end{array}$ & Mean & $\begin{array}{l}\text { Standard } \\
\text { Deviation }\end{array}$ \\
Benevolence & 0.066 & 0.724 & 0.355 & 0.570 \\
Universalism & 0.165 & 0.570 & 0.415 & 0.541 \\
Security & 0.412 & 0.639 & 0.281 & 0.628 \\
Conformity & -0.056 & 0.765 & -0.011 & 0.720 \\
Tradition & -0.379 & 0.847 & -0.256 & 0.705 \\
Self-direction & 0.154 & 0.698 & 0.536 & 0.613 \\
Stimulation & -0.367 & 0.827 & -0.110 & 0.748 \\
Hedonism & 0.176 & 0.680 & 0.065 & 0.669 \\
Achievement & 0.051 & 0.656 & -0.714 & 0.743 \\
Power & -0.306 & 0.919 & -0.769 & 0.772 \\
Locavorism & 4.205 & 0.903 & 4.237 & 0.961 \\
Long-term orientation & 5.599 & 1.034 & 4.444 & 1.221 \\
Fresh start mindset & 5.576 & 1.0585 & 5.187 & 1.215 \\
Attitudes & 5.262 & 1.0916 & 5.953 & 1.114 \\
Intention & 5.446 & 1.084 & 5.538 & 1.328 \\
\hline
\end{tabular}

Note: The means and standard deviations for the 10 value domains are standardized values. A 6-point scale was used to measure the 10 value domains. The locavorism, long-term orientation, fresh start mindset, attitudes and intention were measured by a 7-point scale. 
Table 4

Correlations between the 10 value domains, locavorism and fresh start mindset.

\begin{tabular}{|c|c|c|c|c|c|c|c|c|c|c|c|c|}
\hline & Ben & Uni & $\mathrm{Sec}$ & Con & Trad & Self & Stim & Hed & Achi & Pow & Loca & FSM \\
\hline Ben & - & $0.359 * *$ & 0.005 & -0.049 & -0.062 & $-0.166^{* *}$ & $-0.269^{* *}$ & $-0.290^{* *}$ & $-0.235^{* *}$ & $-0.276^{* *}$ & $0.165^{* *}$ & 0.07 \\
\hline Uni & $0.213^{* *}$ & - & $0.173 * *$ & -0.041 & -0.036 & $-0.215^{* *}$ & $-0.278^{* *}$ & $-0.317^{* *}$ & $-0.351 * *$ & $-0.367 * *$ & 0.072 & 0.021 \\
\hline $\mathrm{Sec}$ & -0.067 & -0.067 & - & 0.012 & -0.033 & $-0.219 * *$ & $-0.251 * *$ & $-0.176^{* *}$ & $-0.216^{* *}$ & $-0.163 * *$ & $-0.128^{*}$ & $-0.149^{*}$ \\
\hline Con & 0.017 & -0.097 & $0.293^{* *}$ & - & $0.193^{* *}$ & $-0.254 * *$ & $-0.242 * *$ & $-0.192 * *$ & $-0.152 *$ & $-0.280^{* *}$ & 0.081 & 0.057 \\
\hline Trad & 0.037 & $-0.133^{*}$ & $0.178 * *$ & $0.324^{* *}$ & - & $-0.147^{*}$ & $-0.253^{* *}$ & $-0.294 * *$ & $-0.239 * *$ & $-0.249 * *$ & $0.189^{* *}$ & 0.081 \\
\hline Self & $-0.188 * *$ & -0.097 & $-0.157^{* *}$ & $-0.446^{* *}$ & $-0.242^{* *}$ & - & $0.154 * *$ & -0.039 & -0.025 & -0.021 & -0.061 & -0.078 \\
\hline Stim & $-0.134 *$ & 0.017 & $-0.413 * *$ & $-0.380 * *$ & $-0.368^{* *}$ & $0.256^{* *}$ & - & $0.127^{*}$ & -0.018 & -0.019 & -0.055 & -0.05 \\
\hline Hed & $-0.246^{* *}$ & $-0.216^{* *}$ & $-0.228 * *$ & $-0.308^{* *}$ & $-0.268^{* *}$ & $0.151 * *$ & $0.179 * *$ & - & $0.240 * *$ & 0.08 & -0.116 & 0.07 \\
\hline Achi & $-0.227 * *$ & $-0.293 * *$ & $-0.228 * *$ & $-0.178 * *$ & $-0.237 * *$ & $-0.146^{*}$ & -0.088 & -0.061 & - & $0.152 *$ & -0.029 & 0.058 \\
\hline Pow & $-0.246^{* *}$ & $-0.414 * *$ & $-0.187 * *$ & $-0.218^{* *}$ & $-0.239 * *$ & -0.026 & $-0.136^{*}$ & 0.024 & $0.334 * *$ & - & $-0.147^{*}$ & -0.083 \\
\hline Loca & $0.131 *$ & 0.08 & -0.067 & -0.072 & -0.067 & -0.096 & $0.125^{*}$ & -0.065 & 0.054 & -0.039 & - & $0.437 * *$ \\
\hline FSM & 0.059 & $-0.130 *$ & -0.074 & -0.03 & -0.027 & -0.074 & $0.183 * *$ & $0.126^{*}$ & 0.074 & -0.092 & $0.303^{* *}$ & - \\
\hline
\end{tabular}

Notes: $\mathrm{Ben}=$ benevolence, $\mathrm{Uni}=$ universalism, $\mathrm{Sec}=$ security, $\mathrm{Con}=$ conformity, Trad $=$ tradition, Self $=$ self-direction, Stim $=$ stimulation, $\mathrm{Hed}=$ hedonism, Achi $=$ achievement, Pow $=$ power, $\mathrm{FSM}=$ fresh start mindset, Loca $=$ locavorism. The Denmark results are below the diagonal, and the China results are above the diagonal.

\subsection{Estimation of structural models}

We built an integrated model including measurement and structure models of all the latent constructs and their indicators to test the hypotheses. First, we tested the integrated model separately with the Chinese sample and the Danish sample. The results show that the integrated model provides a good overall fit for the two samples (Chinese sample: chi-square $=669.969,359 \mathrm{df} ; \mathrm{CMIN} / \mathrm{df}=1.866$; $\mathrm{CFI}=0.935$; TLI $=0.926$; RMSEA $=0.056$; Danish sample: chi-square $=768.251,359 \mathrm{df} ; \mathrm{CMIN} / \mathrm{df}=2.14 ; \mathrm{CFI}=0.918 ; \mathrm{TLI}=0.907 ; \mathrm{RMSEA}=$ 0.061). Table 5 displays the parameter estimates for the hypotheses. The data show that collectivistic values (benevolence) are significantly and positively related to locavorism in both China and Denmark, suggesting that the more individuals value collective benefits, the stronger is their belief in locavorism. Thus, H1 is supported. In China, participants' individualistic values (stimulation) have no significant effect on locavorism, whereas in Denmark, individualistic values have a significantly positive relationship to locavorism. The influence of individualistic values on the individuals' belief of locavorism is only salient in Denmark. Thus, $\mathrm{H} 2$ is supported. The parameters in Table 5 show that the influence of collectivistic values on fresh start mindset is not significant for the two samples; by contrast, the influence of individualistic values on fresh start mindset is not significant in China but positive and significant in Denmark, in support of H3. The data show that long-term orientation is significantly and positively related to locavorism and fresh start mindset for both 
the Chinese and Danish samples; that is, the stronger the long-term orientation, the greater are the individuals' locavorism and fresh start mindset in the two countries, in support of H4. In the two samples, locavorism is significantly and positively related to individuals' attitude towards buying local foods, in support of H5. Fresh start mindset is significantly and positively associated with individuals' intention to purchase local foods in the two countries. Thus, the data support H6. Consistent with predictions (H7), attitude towards buying local foods has a significant and positive influence on intentions to purchase local foods. We further conducted a multi-group structural analysis to compare the influences of values on locavorism and fresh start mindset. We built a multi-group integrated structural model with all the parameters constrained to be equal except for those for the effects of the value domains. The constrained integrated model fits the data well (chi-square $=1,470.08$, $725 \mathrm{df} ; \mathrm{CMIN} / \mathrm{df}=2.028 ; \mathrm{CFI}=0.924 ; \mathrm{TLI}=0.914 ; \mathrm{RMSEA}=0.042)$. Table 6 shows the parameter estimates. The results indicate that collectivistic values are significantly and positively related to locavorism in the two samples, and the influence of individualistic values on locavorism is only significant and positive in the Danish sample. Again, H1 is supported: the influence of individualistic values on fresh start mindset is significant and positive in the Danish sample but not in the Chinese sample, consistent with the results from unconstrained model.

\section{Table 5}

Standardized coefficients for the structural model (unconstrained model).

\begin{tabular}{|c|c|c|c|c|c|c|c|c|c|c|}
\hline \multirow[b]{2}{*}{ Hypotheses } & & \multirow{2}{*}{\multicolumn{2}{|c|}{ Paths }} & \multicolumn{3}{|c|}{ China $(N=282)$} & \multicolumn{3}{|c|}{ Denmark $(\mathrm{N}=306)$} & \multirow[t]{2}{*}{ Results } \\
\hline & & & & $\begin{array}{c}\text { Standardized } \\
\text { loadings }\end{array}$ & $\mathrm{t}$ & $p$ & $\begin{array}{c}\text { Standardized } \\
\text { loadings }\end{array}$ & $\mathrm{t}$ & $\mathrm{p}$ & \\
\hline H1 & $\begin{array}{l}\text { Collectivistic } \\
\text { value }\end{array}$ & $\rightarrow$ & Locavorism & 0.226 & 3.427 & $<0.001$ & 0.186 & 3.028 & $<0.01$ & Supported \\
\hline $\mathrm{H} 2$ & $\begin{array}{l}\text { Individualistic } \\
\text { value }\end{array}$ & $\rightarrow$ & Locavorism & & & 0.971 & 0.172 & 2.827 & $<0.01$ & Supported \\
\hline $\mathrm{H} 3 \mathrm{a}$ & $\begin{array}{l}\text { Collectivistic } \\
\text { value }\end{array}$ & $\rightarrow$ & $\begin{array}{l}\text { Fresh start } \\
\text { mindset }\end{array}$ & 0.081 & 1.438 & 0.151 & 0.093 & 1.677 & 0.094 & Supported \\
\hline $\mathrm{H} 3 \mathrm{~b}$ & $\begin{array}{l}\text { Individualistic } \\
\text { value }\end{array}$ & & $\begin{array}{l}\text { Fresh start } \\
\text { mindset }\end{array}$ & & & 0.886 & 0.141 & 2.531 & $<0.05$ & Supported \\
\hline $\mathrm{H} 4 \mathrm{a}$ & $\begin{array}{l}\text { Long-term } \\
\text { orientation }\end{array}$ & $\rightarrow$ & Locavorism & 0.471 & 5.097 & $<0.001$ & 0.402 & 4.587 & $<0.001$ & Supported \\
\hline $\mathrm{H} 4 \mathrm{~b}$ & $\begin{array}{l}\text { Long-term } \\
\text { orientation }\end{array}$ & $\rightarrow$ & $\begin{array}{l}\text { Fresh start } \\
\text { mindset }\end{array}$ & 0.611 & 6.259 & $<0.001$ & 0.466 & 6.644 & $<0.001$ & Supported \\
\hline H5 & Locavorism & $\rightarrow$ & Attitudes & 0.736 & 8.766 & $<0.001$ & 0.692 & 6.661 & $<0.001$ & Supported \\
\hline H6 & $\begin{array}{l}\text { Fresh start } \\
\text { mindset }\end{array}$ & $\rightarrow$ & Intention & 0.139 & 3.437 & $<0.001$ & 0.108 & 2.356 & $<0.05$ & Supported \\
\hline $\mathrm{H} 7$ & Attitudes & $\rightarrow$ & Intention & 0.833 & 17.998 & $<0.001$ & 0.746 & 14.241 & $<0.001$ & Supported \\
\hline
\end{tabular}

\section{Table 6}

Standardized coefficients for the structural model (constrained model). 


\begin{tabular}{|c|c|c|c|c|c|c|c|c|c|c|c|}
\hline & & & & China ( & $\mathrm{N}=282)$ & & Denmark & $\mathrm{k}(\mathrm{N}=3$ & 06) & Results & \\
\hline Hypotheses & & Paths & & Standardized & & & Standardized & & & & \\
\hline $\mathrm{H} 1$ & Collectivistic value & $\rightarrow$ & Locavorism & 0.235 & 3.525 & $<0.00$ & 0.196 & 3.308 & $<0.001$ & Supported & No \\
\hline $\mathrm{H} 2$ & Individualistic value & $\rightarrow$ & Locavorism & & & 0.89 & 0.16 & 2.72 & $<0.01$ & Supported & No \\
\hline H3a & Collectivistic value & $\rightarrow$ & Fresh start mindset & 0.084 & 1.471 & 0.141 & 0.093 & 1.699 & 0.089 & Supported & No \\
\hline $\mathrm{H} 3 \mathrm{~b}$ & Individualistic value & $\rightarrow$ & Fresh start mindset & & & 0.89 & 0.135 & 2.455 & $<0.05$ & Supported & No \\
\hline $\mathrm{H} 4 \mathrm{a}$ & Long-term orientation & $\rightarrow$ & Locavorism & 0.426 & 7.065 & $<0.00$ & 0.45 & 7.065 & $<0.001$ & Supported & Yes \\
\hline $\mathrm{H} 4 \mathrm{~b}$ & Long-term orientation & $\rightarrow$ & Fresh start mindset & 0.586 & 9.465 & $<0.00$ & 0.493 & 9.465 & $<0.001$ & Supported & Yes \\
\hline H5 & Locavorism & $\rightarrow$ & Attitudes & 0.688 & 10.942 & $<0.00$ & 0.728 & 10.942 & $<0.001$ & Supported & Yes \\
\hline H6 & Fresh start mindset & $\rightarrow$ & Intention & 0.116 & 4.058 & $<0.00$ & 0.133 & 4.058 & $<0.001$ & Supported & Yes \\
\hline $\mathrm{H} 7$ & Attitudes & $\rightarrow$ & Intention & 0.844 & 22.829 & $<0.00$ & 0.729 & 22.829 & $<0.001$ & Supported & Yes \\
\hline
\end{tabular}

Note: Table 6 shows the standardized loadings of each path; therefore, the values are not equal in the two samples.

\section{Discussion}

In tandem with consumers' growing interest in local foods, researchers have paid increasing attention to the determinants of local food consumption. Although previous research has provided important insights into consumers' motives for buying local foods, studies conducted simultaneously in different countries are lacking (for an exception, see Bianchi \& Mortimer, 2015). The purposes of this study are to develop an integrated model including values, beliefs (locavorism and fresh start mindset), and attitudes towards and intentions to buy local foods and to test the model in two countries. The empirical results are consistent with our theoretical predictions. They show that individual values and long-term orientation effectively predict locavorism and fresh start mindset. Specifically, collectivistic values have a significant and positive influence on locavorism in both China and Denmark, but the antecedent effects of individualistic values on locavorism exists only in Denmark. In China, individualistic values have no significant influence on locavorism, but in Denmark, the positive relationship between individualistic values and locavorism is salient. Collectivistic values reflect a key concern with collective interests (Schwartz, 1992), such as the concern for the well-being of others. Local food consumption is viewed as beneficial to the local community and the environment. Intuitively, the more individuals value collective interests, the stronger is the locavorism. Research from the sustainable food consumption domain shows that collectivistic values (universalism) are positively related to consumer buying motives and attitudes towards organic food in China and Brazil, similar to findings in Europe and North America (Thøgersen, de Barcellos, Perin, \& Zhou, 2015). Thus, a tentative conclusion could be it could be concluded that the influence of collectivistic values on locavorism exists in different countries. China scores lower on the individualism dimension than Denmark (House et al., 2004). Individualistic values prioritise the key issues of personal concerns (Schwartz, 1992). The lionisation dimension of locavorism implies that local foods have superior taste and quality, and the opposition dimension describes local foods as more trustworthy, safe, and transparent due to the short distance of food transportation. These beliefs are closely relevant to personal hedonic and functional benefits. In addition, our results show that the individualistic value 
(stimulation) is positively related to locavorism, which is consistent with the findings of Nie and Zepeda (2011) that adventurous consumers have greater preferences for local foods and shop at farmers' market more frequently than conservative uninvolved consumers.

Consistent with our expectations, the data show that long-term orientation is associated with stronger locavorism and greater fresh start mindset. To our knowledge, researchers have not investigated the relationship between long-term orientation and local food consumption directly. Considering that local foods possess functional/healthy/sustainable attributes, findings from relevant research could provide some insights into the relationship between local foods and long-term orientation. For example, Corral-Verdugo, Fraijo-Sing, and Pinheiro (2006) show that long-term orientation significantly and positively influences consumers' sustainable behaviour. In addition, Price et al. (2018) confirm the positive correlation between fresh start mindset and long-term orientation, but they mainly focus on the development of the measurement scale of fresh start mindset. Our work explicitly and empirically examines long-term orientation acting as a predictor of fresh start mindset.

Fresh start mindset is a novel construct introduced by Price et al. (2018). Almost no research has investigated its antecedents and outcomes. Although researchers have proposed that consumers with a fresh start mindset are more likely to behave sustainably (White et al., 2019), existing research has not verified this proposition. In this study, we find that individualistic values are strongly related to fresh start mindset, and this effect is mainly salient in Denmark (a country with individualistic-dominated culture), consistent with and providing evidence for the argument that fresh start mindset is founded around individualism (Price et al., 2018). In addition, we find that the fresh start mindset is significantly and positively related to consumer intention to purchase local foods, which expands the fresh start mindset construct by introducing it into local food consumption context.

Abundant research has examined the relationship between attitude towards and intention to buy local foods (for a review, see Feldmann \& Hamm, 2015). The current study shows that attitude towards local foods is a positive predictor of intention to buy local foods, which is consistent with Bianchi and Mortimer's (2015) finding that attitude towards local food consumption is strongly and positively related to intentions to purchase local food in different countries (in Chile and Australia).

In short, this study contributes to the current literature and practice in three ways. First, our work expands local food consumption research by developing and testing an integrated model with values, beliefs, and attitude towards and intention to buy local foods. We introduce two recent belief constructs (locavorism and fresh start mindset) to local food research and address the antecedents and consequences of locavorism. We find the predicted effects of individual values and long-term orientation on locavorism. Second, this work extends local food consumption research by investigating two countries simultaneously. We find that the influence of individual values on beliefs performances differently in China and Denmark. Third, this study provides practical implications for local food marketing. We find an important role of individual values and beliefs in purchasing local foods. Thus, local food marketers could emphasize their marketing communications on the self-beneficial and other-beneficial attributes of local foods to activate consumers' values of personal welfare and concerns for society to promote positive attitudes towards and intentions to consume local foods. For example, local food marketers could use a "local" label with the message that purchasing local foods benefits the environment and the local community; but they could also emphasize that consuming local foods benefits yourself and your descendants in the long-term. 
We acknowledge some limitations of our study. Owing to the large population and territory of China, we used convenience sampling to collect data there. Approximately $82 \%$ of the participants were residents from cities, and most of the participants were young and well-educated people, which limits the representativeness of the Chinese sample. If a more representative sample were used in China, i.e. more participants from the rural areas, with higher age and lower education level were included, we expect that the effects of values on locavorism would be stronger, and the participants' attitudes towards and intention to purchase local foods would be more positive and higher. We have this expectation because individualistic values are rising in China, especially for the young people who tend to endorse cultural values and beliefs different from their parents or grandparents (Sun \& Ryder, 2016). Sun and Wang (2010) have found that people in the younger generations show stronger individualistic values, while the older generation reveals stronger collectivistic values. Sun and Ryder (2016) have shown variations in values in residents from urban and rural places, where urban residents are more likely to focus on self-development. Additionally, people from everywhere have witnessed the globalization. However, urban residents experience it with much greater intensity than rural residents do (Arnett, 2002). Thus, it could be expected that people in rural areas would hold higher locavorism and more positive attitudes towards local food production. Hence, future research could replicate our findings and explore the potential influences of age, education and residence using a more representative Chinese sample. Furthermore, future research could use mixed approaches to test the stability of the relationships among the constructs, such as using panel data to obtain samples from different periods or an experimental design to manipulate fresh start mindset in the local food context. The current research investigates consumers' attitudes towards and intentions to purchase general local foods. Future research could include specific products or product categories to tease out whether consumer attitudes and intentions are stronger for certain items. In addition, researchers could explore the functional conditions of the values-beliefs-attitude model of local food consumption.

Funding: This work was supported by the National Natural Science Foundation of China (No. 71872194, 71372153), the Natural Science Foundation of Guangdong Province (No.2016A030313764), the China Scholarship Council (CSC), and the Guangzhou Center for Innovative Communication in International Cities (No.2018-IC-04).

\section{Appendix}

Measurement instruments

\begin{tabular}{l}
\hline Variables \\
\hline Locavorism \\
Lionization \\
Locally produced foods just taste better. \\
All else equal, there is no taste difference between a locally produced food and one that was shipped \\
from somewhere else (reverse-coded). \\
Locally produced foods are more nutritious than foods that have been shipped from somewhere else. \\
Opposition
\end{tabular}


I don't trust foods that have been produced by large, multinational corporations.

Large, global food systems are destined to fail.

I would go out of my way to avoid buying food from a large retail grocery chain.

I feel uneasy eating something unless I know exactly where it was produced.

Communalization

Buying locally produced foods supports sustainable farming practices.

Buying local foods helps build a more prosperous community.

I like to support local farmers whenever possible.

Supporting the local food economy is important to me.

\section{Collectivistic values}

Benevolence

It is very important to him/her to help people around him/her. He/She wants to take care for their well-being.

Loyalty to friends is very important to him/her. He/She wants to devote himself/herself to people close to $\mathrm{him} / \mathrm{her}$.

\section{Universalism}

Listening to opinions different from his/her is important for him/her. He/She would try to understand others' opinion even if he/she does not agree with what they say.

$\mathrm{He} / \mathrm{She}$ thinks it is important that all people in the world get the same treatment. He/She believes everyone should enjoy equal opportunity in life.

$\mathrm{He} / \mathrm{She}$ believes that everyone should care about nature. The protection of ecological environment is rather important for him/her.

Security

Living in a secure environment is important for him/her. He/She would do his/her best to avoid anything that will endanger his/her safety.

It is important to him/her that the government ensures his/her safety against all threats. He/She wants the state to be strong so it can defend its citizens.

Conformity

$\mathrm{He} /$ She believes that people should do as others say and abide by the rules even if no one is watching.

Dignified manner is important for him/her. He/She would do his/her best not to do things others think wrong.

\section{Tradition}

Modesty is important for him/her. He/She would do his/her best not to arouse others' attention.

Tradition is important to him/her. He/She tries to follow the customs handed down by his/her religion or his/her family.

Individualistic values

Self-direction 
Making decisions on one's own is important for him/her. He/She likes freedom and independent.

To have new ideas and be innovative is important for him/her. He/She likes to do things in his/her own way.

\section{Stimulation}

$\mathrm{He} / \mathrm{She}$ likes surprises and is always looking for new things. He/She thinks it is important to do many different things in life.

$\mathrm{He} / \mathrm{She}$ likes and also often looks for adventurous activity. He/She hopes to have an exciting life.

\section{Hedonism}

To enjoy happiness is important for him/her. He/She favours himself/herself.

$\mathrm{He} / \mathrm{She}$ seeks every chance he/she can to have fun. It is important to him/her to do things that give $\mathrm{him} /$ her pleasure.

Achievement

To show oneself is important for him/her. He/She wants people to admire what he/she does.

For him/her, to be successful in career is important. He/She likes to give others a good impression.

\section{Power}

To be rich is important for him/her. He/She wants to possess a lot of money and expensive things.

For him/her, to gain respect from others is important. He/She likes others to do as he/she says.

Please select the circle closest to "Very much like me" for this question (attention check)

\section{Long-term orientation}

I plan for the long term.

I work hard for success in the future.

I don't mind give up today's fun for success in the future.

Attitude towards buying local food

Buying local food is (Harmful, Beneficial)

Buying local food is (Foolish, Wise)

Buying local food would make me feel (Bad, Good)

Buying local food would make me feel (Displeased, Pleased)

Intention to purchase local foods

How likely is it that you will purchase local foods?

How likely is it that you will buy your basic food items from a neighbourhood grocery store that offers locally produced food items?

Next time when you buy a food, you will take local foods into consideration.

Fresh start mindset

Regardless of present circumstances, someone can chart a new course in life.

Anyone can make a new start if they want to.

It's always possible for someone to get a new beginning.

Whatever their past, people can look forward to a new future. 
An individual can let go of the past and start anew.

When something bad happens, a person can choose to create a better life.

\section{References}

Adams, D. C., \& Adams, A. E. (2011). De-placing local at the farmers' market: Consumer conceptions of local foods. Journal of Rural Social Sciences, 26(2), 74-100.

Adams, M. (2018). The aesthetic value of local food. The Monist, 101, 324-339.

Anderson, L., Ostrom, A. L., Corus, C., Fisk, R. P., Gallan, A. S., Giraldo, M., ... \& Shirahada, K. (2013). Transformative service research: An agenda for the future. Journal of Business Research, 66(8), 1203-1210. Ajzen, I., \& Fishbein, M. (1980). Understanding attitudes and predicting social behavior. Englewood Cliffs, NJ: Prentice Hall.

Arnett, J. J. (2002). The psychology of globalization. American psychologist, 57(10), 774-783.

Bavorova, M., Unay-Gailhard, I., \& Lehberger, M. (2016). Who buys from farmers' markets and farm shops? The case of Germany. International Journal of Consumer Studies, 40(1), 107-114.

Bearden, W. O., Money, R. B., \& Nevins, J. L. (2006). A measure of long-term orientation: Development and validation. Journal of the Academy of Marketing Science, 34(3), 456-467.

BMEL (2018). Deutschland, wie es isst. Der BMEL-Ernährungsreport 2018 [Germany: How it eats-The BMEL nutrition report 2018].

https://www.bmel.de/SharedDocs/Downloads/Broschueren/Ernaehrungsreport2018.pdf? blob=publicationFil e [Accessed July 11, 2019].

Bianchi, C., \& Mortimer, G. (2015). Drivers of local food consumption: A comparative study. British Food Journal, 117(9), 2282-2299.

Bilsky, W., Janik, M., \& Schwartz, S. H. (2011). The structural organization of human values: Evidence from three rounds of the European Social Survey (ESS). Journal of Cross-Cultural Psychology, 42(5), 759-776.

Birch, D., Memery, J., \& Kanakaratne, M. D. S. (2018). The mindful consumer: Balancing egoistic and altruistic motivations to purchase local food. Journal of Retailing and Consumer Services, 40, 221-228.

Blake, M. K., Mellor, J., \& Crane, L. (2010). Buying local food: Shopping practices, place, and consumption networks in defining food as "local". Annals of the Association of American Geographers, 100(2), 409-426.

Bolos, L. A., Lagerkvist, C. J., \& Kulesz, M. M. (2019). Complementarity of implicit and explicit attitudes in predicting the purchase likelihood of visually sub-optimal or optimal apples. Food Quality and Preference, 75, 87-96.

Campbell, J. M. (2013). Muy local: Differentiating Hispanic and Caucasian shoppers of locally produced foods in US grocery. Journal of Retailing and Consumer Services, 20(3), 325-333.

Canadian Food Inspection Agency (CFIA). (2019). Local food claims interim policy. http://www.inspection.gc.ca/food/requirements-and-guidance/labelling/industry/origin/local-food-claims/eng/1 368135927256/1368136146333 [Accessed July 30, 2019].

Caracciolo, F., Cicia, G., Del Giudice, T., Cembalo, L., Krystallis, A., Grunert, K. G., \& Lombardi, P. (2016). Human values and preferences for cleaner livestock production. Journal of Cleaner Production, 112, 121-130.

Carroll, B. E., \& Fahy, F. (2014). Locating the locale of local food: The importance of context, space and social relations. Renewable Agriculture and Food Systems, 30(6), 563-576. 
Cembalo, L., Caracciolo, F., Lombardi, A., Del Giudice, T., Grunert, K. G., \& Cicia, G. (2016). Determinants of individual attitudes toward animal welfare-friendly food products. Journal of Agricultural and Environmental Ethics, 29(2), 237-254.

Chambers, S., Lobb, A., Butler, L., Harvey, K., \& Traill, W. B. (2007). Local, national and imported foods: A qualitative study. Appetite, 49(1), 208-213.

Coelho, F. C., Coelho, E. M., \& Egerer, M. (2018). Local food: Benefits and failings due to modern agriculture. Scientia Agricola, 75(1), 84-94.

Conner, D. S., Montri, A. D., Montri, D. N., \& Hamm, M. W. (2009). Consumer demand for local produce at extended season farmers' markets: Guiding farmer marketing strategies. Renewable Agriculture and Food Systems, 24(4), 251-259.

Corral-Verdugo, V., Fraijo-Sing, B., \& Pinheiro, J. Q. (2006). Sustainable behavior and time perspective: Present, past, and future orientations and their relationship with water conservation behavior. Interamerican Journal of Psychology, 40(2), 139-147.

Costanigro, M., Kroll, S., Thilmany, D., \& Bunning, M. (2014). Is it love for local/organic or hate for conventional? Asymmetric effects of information and taste on label preferences in an experimental auction. Food Quality and Preference, 31, 94-105.

Cranfield, J., Henson, S., \& Blandon, J. (2012). The effect of attitudinal and sociodemographic factors on the likelihood of buying locally produced food. Agribusiness, 28(2), 205-221.

Darby, K., Batte, M. T., Ernst, S., \& Roe, B. (2008). Decomposing local: A conjoint analysis of locally produced foods. American Journal of Agricultural Economics, 90(2), 476-486.

Dassen, F. C., Houben, K., \& Jansen, A. (2015). Time orientation and eating behavior: Unhealthy eaters consider immediate consequences, while healthy eaters focus on future health. Appetite, 91, 13-19.

Davidov, E., Schmidt, P., \& Schwartz, S. H. (2008). Bringing values back in: The adequacy of the European Social Survey to measure values in 20 countries. Public Opinion Quarterly, 72(3), 420-445.

de Boer, J., Schösler, H., \& Aiking, H. (2017). Towards a reduced meat diet: Mindset and motivation of young vegetarians, low, medium and high meat-eaters. Appetite, 113, 387-397.

Denver, S., \& Jensen, J. D. (2014). Consumer preferences for organically and locally produced apples. Food Quality and Preference, 31, 129-134.

Feldmann, C., \& Hamm, U. (2015). Consumers' perceptions and preferences for local food: A review. Food Quality and Preference, 40, 152-164.

Fitzgerald, K. J. (2016). Thinking globally, acting locally: Locavorism and humanist sociology. Humanity \& Society, 40(1), 3-21.

Gkargkavouzi, A., Halkos, G., \& Matsiori, S. (2019). Environmental behavior in a private-sphere context: Integrating theories of planned behavior and value belief norm, self-identity and habit. Resources, Conservation and Recycling, 148, 145-156.

Guagnano, G. A., Stern, P. C., \& Dietz, T. (1995). Influences on attitude-behavior relationships: A natural experiment with curbside recycling. Environment and Behavior, 27(5), 699-718.

Hempel, C., \& Hamm, U. (2016). How important is local food to organic-minded consumers? Appetite, 96(2016),309-318.

Hofstede, G., \& Minkov, M. (2010). Long-versus short-term orientation: new perspectives. Asia Pacific Business Review, 16(4), 493-504. 
House R. J., Hanges P. J., Javidan M., et al. (2004). Culture, leadership, and organizations: The GLOBE Study of 62 societies (pp. 9-50). Thousand Oaks, CA: SAGE Publications.

Jekanowski, M. D., Williams, D. R., \& Schiek, W. A. (2000). Consumers' willingness to purchase locally produced agricultural products: An analysis of an Indiana survey. Agricultural and Resource Economics Review, 29(1), 43-53.

Joireman, J., Shaffer, M. J., Balliet, D., \& Strathman, A. (2012). Promotion orientation explains why future-oriented people exercise and eat healthy: Evidence from the two-factor consideration of future consequences-14 scale. Personality and Social Psychology Bulletin, 38(10), 1272-1287.

Kang, J., Jun, J., \& Arendt, S. W. (2015). Understanding customers' healthy food choices at casual dining restaurants: Using the value-attitude-behavior model. International Journal of Hospitality Management, 48, $12-21$.

Kim, H. S., \& Drolet, A. (2003). Choice and self-expression: A cultural analysis of variety-seeking. Journal of Personality and Social Psychology, 85(2), 373-382.

Kopalle, P. K., Lehmann, D. R., \& Farley, J. U. (2010). Consumer expectations and culture: The effect of belief in karma in India. Journal of Consumer Research, 37(2), 251-263.

Macdonnell, R., \& White, K. (2015). How construals of money versus time impact consumer charitable giving. Journal of Consumer Research, 42(4), 551-563.

Martinez, S., Hand, M., Pra, M. D., Pollack, S., Ralston, K., Smith, T., Vogel, S., Clark, S., Lohr, L., Low, S., \& Newman, C. (2010). Local food systems concepts, impacts, and issues. Washington, DC: USDA-Economic Research Service.

Menozzi, D., Sogari, G., Veneziani, M., Simoni, E., \& Mora, C. (2017). Eating novel foods: An application of the Theory of Planned Behaviour to predict the consumption of an insect-based product. Food Quality and Preference, 59, 27-34.

Meyerding, S. G., Trajer, N., \& Lehberger, M. (2019). What is local food? The case of consumer preferences for local food labeling of tomatoes in Germany. Journal of Cleaner Production, 207, 30-43.

Mick, D. G., Pettigrew, S., Pechmann, C. C., \& Ozanne, J. L. (Eds.). (2012). Transformative consumer research for personal and collective well-being. New York: Routledge.

Mørk, T., Bech-Larsen, T., Grunert, K. G., \& Tsalis, G. (2017). Determinants of citizen acceptance of environmental policy regulating consumption in public settings: Organic food in public institutions. Journal of Cleaner Production, 148, 407-414.

Nie, C., \& Zepeda, L. (2011). Lifestyle segmentation of US food shoppers to examine organic and local food consumption. Appetite, 57(1), 28-37.

Perrea, T., Grunert, K. G., Krystallis, A., Zhou, Y. F., Huang, G., \& Hue, Y. (2014). Testing and validation of a hierarchical values-attitudes model in the context of green food in China. Asia Pacific Journal of Marketing and Logistics, 26(2), 296-314.

Price, L. L., Coulter, R. A., Strizhakova, Y., \& Schultz, A. E. (2018). The fresh start mindset: Transforming consumers' lives. Journal of Consumer Research, 45(1), 21-48.

Qi, X., \& Ploeger, A. (2019). Explaining consumers' intentions towards purchasing green food in Qingdao, China: The amendment and extension of the theory of planned behavior. Appetite, 133, 414-422.

Reczek, R. W., Trudel, R., \& White, K. (2018). Focusing on the forest or the trees: How abstract versus concrete construal level predicts responses to eco-friendly products. Journal of Environmental Psychology, 57, 
87-98.

Reich, B. J., Beck, J. T., \& Price, J. (2018). Food as ideology: Measurement and validation of locavorism. Journal of Consumer Research, 45(4), 849-868.

Reich, T., Kupor, D. M., \& Smith, R. K. (2017). Made by mistake: When mistakes increase product preference. Journal of Consumer Research, 44(5), 1085-1103.

Roininen, K., Arvola, A., \& Lähteenmäki, L. (2006). Exploring consumers' perceptions of local food with two different qualitative techniques: Laddering and word association. Food Quality and Preference, 17(1/2), 20-30. Rucker, D. D., \& Galinsky, A. D. (2016). Growing beyond growth: Why multiple mindsets matter for consumer behavior. Journal of Consumer Psychology, 26(1), 161-164.

Rudy, K. (2012). Locavores, feminism, and the question of meat. Journal of American Culture, 35(1), 26-36.

Schmitt, E., Galli, F., Menozzi, D., Maye, D., Touzard, J. M., Marescotti, A., \& Brunori, G. (2017). Comparing the sustainability of local and global food products in Europe. Journal of Cleaner Production, 165, 346-359.

Schwartz, S. H. (1992). Universals in the content and structure of values: theoretical advances and empirical tests in 20 countries. In Zanna, M. P. (Ed.), Advances in experimental social psychology (pp. 1-65). San Diego, CA: Academic Press.

Schwartz, S. H. (1994). Are there universal aspects in the structure and contents of human values? Journal of Social Issues, 50(4), 19-45.

Schwartz, S. H., \& Boehnke, K. (2004). Evaluating the structure of human values with confirmatory factor analysis. Journal of Research in Personality, 38(3), 230-255.

Schwartz, S. H., Melech, G., Lehmann, A., Burgess, S., Harris, M., \& Owens, V. (2001). Extending the cross-cultural validity of the theory of basic human values with a different method of measurement. Journal of Cross-Cultural Psychology, 32(5), 519-542.

Sellberg, M. M., Norström, A. V., Peterson, G. D., \& Gordon, L. J. (2020). Using local initiatives to envision sustainable and resilient food systems in the Stockholm city-region. Global Food Security, 24(2020),100334.

Skallerud, K., \& Wien, A. H. (2019). Preference for local food as a matter of helping behaviour: Insights from Norway. Journal of Rural Studies, 67, 79-88.

Sun, J., \& Wang, X. (2010). Value differences between generations in China: A study in Shanghai. Journal of Youth Studies, 13(1), 65-81.

Sun, J., \& Ryder, A. G. (2016). The Chinese experience of rapid modernization: Sociocultural changes, psychological consequences?. Frontiers in Psychology, 7, 477,1-13.

Stanton, J. L., Wiley, J. B., \& Wirth, F. F. (2012). Who are the locavores? Journal of Consumer Marketing, 29(4), 248-261.

Steenkamp, J. B. E., \& Baumgartner, H. (1998). Assessing measurement invariance in cross-national consumer research. Journal of Consumer Research, 25(1), 78-90.

Stern, P. C., \& Dietz, T. (1994). The value basis of environmental concern. Journal of Social Issues, 50(3), 6584.

Stern, P. C., Dietz, T., Abel, T., Guagnano, G. A., \& Kalof, L. (1999). A value-belief-norm theory of support for social movements: The case of environmentalism. Human Ecology Review, 6(2), 81-97.

Thøgersen, J., de Barcellos, M. D., Perin, M. G., \& Zhou, Y. (2015). Consumer buying motives and attitudes towards organic food in two emerging markets: China and Brazil. International Marketing Review, 32(3/4), 
389-413.

Thøgersen, J., Zhou, Y., \& Huang, G. (2016). How stable is the value basis for organic food consumption in China? Journal of Cleaner Production, 134, 214-224.

Thomas, L. N., \& Mcintosh, W. A. (2013). "It just tastes better when it's in season": Understanding why locavores eat close to home. Journal of Hunger \& Environmental Nutrition, 8(1), 61-72.

Venaik, S., Zhu, Y., \& Brewer, P. (2013). Looking into the future: Hofstede long term orientation versus GLOBE future orientation. Cross Cultural Management: An International Journal, 20(3), 361-385.

Vilsack T. (2016). New markets, new opportunities: Strengthening local food systems and organic agriculture.

https://medium.com/usda-results/new-markets-new-opportunities-strengthening-local-food-systems-and-organi c-agriculture-17b529c5ea90 April 2016. [Accessed July 11, 2019]

Werthmann, J., Jansen, A., \& Roefs, A. (2016). Make up your mind about food: A healthy mindset attenuates attention for high-calorie food in restrained eaters. Appetite, 105, 53-59.

White, K., Habib, R., \& Hardisty, D. J. (2019). How to SHIFT consumer behaviors to be more sustainable: A literature review and guiding framework. Journal of Marketing, 83(3), 22-49.

Zepeda, L., \& Deal, D. (2009). Organic and local food consumer behaviour: Alphabet theory. International Journal of Consumer Studies, 33(6), 697-705.

Zepeda, L., \& Leviten-Reid, C. (2004). Consumers' views on local food. Journal of Food Distribution Research, 35(3), 1-6.

Zepeda, L., \& Li, J. (2006). Who buys local food? Journal of Food Distribution Research, 37(3), 1-11.

\section{CRediT author statement}

Ting Zhang: Conceptualization, Methodology, Software, Validation, Formal analysis, Investigation, Resources, Data Curation, Writing - Original Draft, Writing - Review \& Editing, Project administration, Funding acquisition. Klaus G. Grunert: Conceptualization, Methodology, Software, Validation, Formal analysis, Investigation, Resources, Data Curation, Writing - Review \& Editing, Supervision, Funding acquisition. Yanfeng Zhou: Validation, Investigation, Resources, Data Curation, Writing - Review \& Editing, Visualization, Supervision, Funding acquisition.

Highlights

- A values-beliefs-attitudes model of local food consumption in China and Denmark

- Collectivistic values are positively related to locavorism in both China and Denmark

- Individualistic values strongly affect locavorism and fresh start mindset in Denmark

- Stronger long-term orientation leads to higher locavorism and fresh start mindset

- Beliefs are positively related to attitudes towards and intentions to buy local foods 